\title{
MAHAR POLITIK DALAM PANDANGAN POLITIK HUKUM DI INDONESIA
}

\author{
Oleh : IDA FARIDA*) \\ (Idafarida.galuh@gmail.com)
}

\begin{abstract}
This article describes and analyzes the political dowry in the view of legal politics in Indonesia. The dynamics of regional head elections in 2018 are still colored by relatively similar issues, one of which is currently appearing on the surface is related to the provision of "political dowry" to political parties bearing the nomination of regional heads. The issue is not new in Indonesia's post-reform elections, especially now that the party is quite pragmatic and oriented towards winning candidates. In participating in political contestation, there are violations of candidates to follow the entire mechanism of the election "democratically" both the internal party mechanism and the external mechanism in accordance with the applicable rules in the Law. Politics of electoral law and post-conflict local elections experience continuous changes along with the development of society, relevance in democratic practices or cultural democracy and changes in legal and political thinking both executive, legislator and society in general.
\end{abstract}

Keywords: Political Dowry, Legal Politics.

\begin{abstract}
Abstrak
Artikel ini mendeskripsikan dan menganalisis mengenai mahar politik dalam pandangan politik hukum di Indonesia. Dinamika pemilihan kepala daerah pada 2018 ini masih diwarnai oleh isu yang relatif sama, salah satu yang saat ini muncul di permukaan adalah terkait pemberian "mahar politik" kepada partai politik pengusung calon kepala daerah. Isu tersebut bukanlah hal yang baru dalam pemilu Indonesia pasca reformasi, terlebih saat ini partai cukup pragmatis dan berorientasi pada kemenangan calon. Dalam mengikuti kontestasi politik, adanya pelanggaranpelanggaran calon untuk mengikuti seluruh mekanisme pemilihan secara "demokratis" baik mekanisme internal partai maupun mekanisme eksternal sesuai dengan aturan yang berlaku dalam Undang-Undang. Politik hukum pemilu dan pemilukada mengalami perubahan terus-menerus seiring dengan perkembangan masyarakat, relevansi dalam praktik ketatanegaraan atau budaya berdemokrasi serta perubahan pemikiran hukum dan politik baik eksekutif, legislator maupun masyarakat pada umumnya.
\end{abstract}

Kata Kunci: Mahar Politik, Politik Hukum

\footnotetext{
${ }^{*}$ Dosen Tetap Fakultas Hukum Universitas Galuh
} 


\section{Pendahuluan}

Demokrasi adalah bentuk pemerintahan dimana semua warga negaranya memiliki hak setara dalam pengambilan keputusan yang dapat mengubah hidup mereka. Demokrasi mengizinkan warga negara berpartisipasi baik secara langsung atau melalui perwakilan dalam perumusan, pengembangan, dan pembuatan hukum. Demokrasi mencakup kondisi sosial, ekonomi, dan budaya yang memungkinkan adanya praktik dan prosedurnya. Demokrasi mengandung makna penghargaan terkadap harkat dan martabat manusia. Indonesia adalah salah satu negara yang menjunjung tinggi demokrasi.

Demokrasi Indonesia dipandang perlu dan sesuai dengan nilai-nilai yang ada di bangsa Indonesia. Sebagai bentuk kesungguhan negara Indonesia, landasan tentang demokrasi telah tertuang dalam Pembukaan Undang-Undang Dasar Negara Republik Indonesia Tahun 1945 (selanjutnya disingkat UUD 1945) maupun Batang Tubuh UUD 1945. Seluruh penyataan dalam UUD 1945 dilandasi oleh jiwa dan semangat demokrasi. Penyusunan naskah UUD 1945 itu sendiri juga dilakukan secara demokratis.

Menurut Hans Kelsen, pengertian demokrasi adalah sistem pemerintahan yang dimana pada setiap keputusan yang diambil oleh pemerintah secara langsung ataupun tidak langsung itu didasari atas hasil kesepakatan mayoritas yang telah diberikan secara bebas untuk rakyat dewasa. Indonesia menganut demokrasi pancasila yang artinya suatu sistem demokrasi yang selalu terpusat pada aspirasi, kepentingan dan dari suara rakyat serta mempunyai jiwa dan dasar dari paham Pancasila atau nilai-nilai luhur dari Pancasila yang dimana bersumber pada setiap tata nilai sosial budaya.

Pendalaman demokrasi menurut Fung dan Olin-Wright (2003) juga diperlukan untuk memenuhi gagasan sentral mengenai demokrasi politik yang meliputi beberapa hal penting, seperti pemberian fasilitas kepada masyarakat agar mereka terlibat dalam politik: mendorong terjadinya konsensus politik melalui dialog, merealisasikan kebijakan publik yang dapat menciptakan efektivitas ekonomi dan masyarakat yang sehat, dan memberikan proteksi agar warga negara juga menikmati kekayaan negara. Dengan demikian akan memungkinkan banyak orang terlibat dalam proses kebijakan di pemerintahan 
lokal. Dengan kata lain, dapat dikatakan bahwa dalam pemerintahan lokal potensi warga tidak hanya dalam keterlibatan di pemilu lokal atau duduknya di parlemen, lebih jauh adalah keterlibatan aktif warganya secara lebih luas. (John Stewar, 1996 : 39).

Munculnya perhatian terhadap transisi demokrasi di daerah itu menurut Brian C Smith (1998) berangkat dari suatu keyakinan bahwa demokrasi di daerah merupakan prasyarat bagi munculnya demokrasi di tingkat nasional. Asumsi ini berangkat bahwa ketika terdapat perbaikan kualitas demokrasi di daerah, secara otomatis bisa diartikan sebagai adanya perbaikan kualitas demokrasi di tingkat nasional. Beberapa alasannya antara lain, demokrasi pemerintahan di daerah merupakan suatu ajang pendidikan politik yang relevan bagi warga negara di dalam suatu masyarakat yang demokratis. Artinya, terdapat unsur proximity bahwa pemerintah daerah merupakan bagian dari pemerintah yang langsung berinteraksi dengan masyarakat ketika proses demokratisasi berlangsung. (Kacung Marijan, 2010:170)

Dinamika pemilihan kepala daerah pada 2018 ini masih diwarnai oleh isu yang relatif sama, salah satu yang saat ini muncul di permukaan adalah terkait pemberian "mahar politik" kepada partai politik pengusung calon kepala daerah. Isu tersebut bukanlah hal yang baru dalam pemilu Indonesia pasca reformasi, terlebih saat ini partai cukup pragmatis dan berorientasi pada kemenangan calon. Konsekuensinya hitungan-hitungan politik untuk memenangkan calon menjadi hal yang prioritas terutama untuk menyikapi besarnya ongkos politik yang harus dikeluarkan oleh para calon.

Berdasarkan hal tersebut, minimal terdapat empat sumber pengeluaran yang menyebabkan tingginya ongkos politik pilkada. Pertama biaya pencalonan (ongkos perahu politik) yang lazim disebut sebagai "mahar politik". Kedua, dana kampanye yang meliputi atribut kampanye, tim pemenangan, serta penggunaan media elektronik dan cetak. Ketiga, ongkos konsultasi dan survey melalui pelbagai lembaga konsultan dan lembaga survey. Keempat, politik uang yang masih marak dilakukan oleh calon kepala daerah meliputi "serangan fajar", sumbangan ke kantong pemilih, dan lainnya. Selain itu, dana yang cukup besar adalah perihal keberadaan saksi pada hari perhitungan suara.

Dalam mengikuti kontestasi politik, adalah sebuah keniscayaan bagi calon untuk mengikuti seluruh mekanisme pemilihan secara "demokratis" baik 
mekanisme internal partai maupun mekanisme eksternal sesuai dengan aturan yang berlaku dalam Undang-Undang. Mekanisme pemilihan calon kepala daerah di dalam partai ini yang seringkali sulit diawasi dan belum adanya transparansi karena bersifat internal atau sekedar formalitas belaka. Sehingga hal ini membuka peluang untuk adanya transaksi "jual-beli" antara para elit partai dengan bakal calon yang akan diusung oleh partai tersebut.

Politik Hukum sebagai salah satu bagian dari ilmu hukum bertugas untuk melihat perubahan-perubahan mana yang perlu diadakan terhadap hukum yang ada agar memenuhi kebutuhan-kebutuhan baru di dalam kehidupan masyarakat. Dengan objek kajian Politik Hukum adalah Hukum. Oleh karena itu maka penulis deskripsikan artikel mengenai "Mahar" Politik Dalam Pandangan Politik Hukum Di Indonesia, hal ini dilandasi karena Indonesia sedang menghadapi musim politik di tahun 2019 sehingga tak dipungkiri pelanggaranpelanggaran terjadi.

\section{PEMBAHASAN}

\section{"Mahar" politik dalam pandangan Politik Hukum di Indonesia.}

Demokrasi Indonesia dipandang perlu dan sesuai dengan nilai-nilai yang ada di bangsa Indonesia. Sebagai bentuk kesungguhan negara Indonesia, landasan tentang demokrasi telah tertuang dalam Pembukaan UUD 1945 maupun Batang Tubuh UUD 1945. Seluruh penyataan dalam UUD 1945 dilandasi oleh jiwa dan semangat demokrasi. Penyusunan naskah UUD 1945 itu sendiri juga dilakukan secara demokratis.

Menurut Hans Kelsen, pengertian demokrasi adalah sistem pemerintahan yang dimana pada setiap keputusan yang diambil oleh pemerintah secara langsung ataupun tidak langsung itu didasari atas hasil kesepakatan mayoritas yang telah diberikan secara bebas untuk rakyat dewasa. Indonesia menganut demokrasi pancasila yang artinya suatu sistem demokrasi yang selalu terpusat pada aspirasi, kepentingan dan dari suara rakyat serta mempunyai jiwa dan dasar dari paham Pancasila atau nilai-nilai luhur dari Pancasila yang dimana bersumber pada setiap tata nilai sosial budaya.

Pendalaman demokrasi menurut Fung dan Olin-Wright (2003) juga diperlukan untuk memenuhi gagasan sentral mengenai demokrasi politik yang 
meliputi beberapa hal penting, seperti pemberian fasilitas kepada masyarakat agar mereka terlibat dalam politik, mendorong terjadinya konsensus politik melalui dialog, merealisasikan kebijakan publik yang dapat menciptakan efektivitas ekonomi dan masyarakat yang sehat, dan memberikan proteksi agar warga negara juga menikmati kekayaan negara. Dengan demikian akan memungkinkan banyak orang terlibat dalam proses kebijakan di pemerintahan lokal. Dengan kata lain, dapat dikatakan bahwa dalam pemerintahan lokal potensi warga tidak hanya dalam keterlibatan di pemilu lokal atau duduknya di parlemen, lebih jauh adalah keterlibatan aktif warganya secara lebih luas. (John Stewart, 1996 : 39).

Munculnya perhatian terhadap transisi demokrasi di daerah itu menurut Brian C Smith (1998) berangkat dari suatu keyakinan bahwa demokrasi di daerah merupakan prasyarat bagi munculnya demokrasi di tingkat nasional. Asumsi ini berangkat bahwa ketika terdapat perbaikan kualitas demokrasi di daerah, secara otomatis bisa diartikan sebagai adanya perbaikan kualitas demokrasi di tingkat nasional. Beberapa alasannya antara lain, demokrasi pemerintahan di daerah merupakan suatu ajang pendidikan politik yang relevan bagi warga negara di dalam suatu masyarakat yang demokratis. Artinya, terdapat unsur proximity bahwa pemerintah daerah merupakan bagian dari pemerintah yang langsung berinteraksi dengan masyarakat ketika proses demokratisasi berlangsung (Kacung Marijan, 2010 : 170).

Konstitusionalitas pengaturan pemilu dan pemilukada diatur dalam bab dan pasal yang berbeda, yaitu pemilu diatur dalam diatur di dalam Bab VII B Pemilu Pasal 22E ayat (2) UUD 1945, yakni : "Pemilihan umum diselenggarakan untuk memilih anggota Dewan Perwakilan Rakyat, Dewan Perwakilan Daerah, Presiden dan Wakil Presiden dan Dewan Perwakilan Rakyat Daerah", yang dilaksanakan secara langsung, umum, bebas, rahasia, jujur, dan adil setiap lima tahun sekali. Sedangkan pemilukada diatur dalam Bab VI Pemerintahan Daerah Pasal 18 ayat (4) UUD 1945 "Gubernur, Bupati, dan Walikota masing-masing sebagai kepala pemerintahan daerah provinsi, kabupaten, dan kota dipilih secara demokratis". Sedangkan Pasal 22E ayat (5) UUD 1945 dinyatakan: "Pemilihan umum diselenggarakan oleh suatu komisi pemilihan umum yang bersifat nasional, tetap dan mandiri." Jadi, konstitusi sudah memisahkan secara jelas antara pemilu dan pilkada. Penyelenggaraan 
pemilihan umum ditegaskan dalam pasal 22E ayat (2) UUD 1945, sedangkan pengaturan tentang pilkada diletakkan pada bab yang terpisah, yaitu pada Bab VI Pemerintahan Daerah Pasal 18 ayat (4) UUD 1945.

Menurut Satjipto Raharjo Politik Hukum adalah aktivitas untuk menentukan suatu pilihan mengenai tujuan dan cara-cara yang hendak dipakai untuk mencapai tujuan hukum dalam masyarakat.

Sedangkan menurut Patmo Wahjono Politik Hukum adalah kebijaksanaan penyelenggara Negara tentang apa yang dijadikan kriteria untuk menghukumkan sesuatu (menjadikan sesuatu sebagai Hukum). Kebijaksanaan tersebut dapat berkaitan dengan pembentukan hukum dan penerapannya.

Menurut L. J. Van Apeldorn Politik Hukum sebagai politik perundangundangan. Politik Hukum berarti menetapkan tujuan dan isi peraturan perundang-undangan. (pengertian politik hukum terbatas hanya pada hukum tertulis saja).

Menurut Mahfud MD Politik Hukum (dikaitkan di Indonesia) adalah sebagai berikut :

1. Bahwa definisi atau pengertian hukum juga bervariasi namun dengan meyakini adanya persamaan substansif antara berbagai pengertian yang ada atau tidak sesuai dengan kebutuhan penciptaan hukum yang diperlukan.

2. Pelaksanaan ketentuan hukum yang telah ada, termasuk penegasan Bellefroid dalam bukunya Inleiding Tot de Rechtswetenschap in Nederland Mengutarakan posisi politik hukum dalam pohon ilmu hukum sebagai ilmu.

Politik hukum merupakan salah satu cabang atau bagian dariilmu hukum, menurutnya ilmu hukum terbagi atas:

Dogmatika Hukum;

a. Sejarah Hukum;

b. Perbandingan Hukum;

c. Politik Hukum.

IImu Hukum Umum Politik Hukum bertugas untuk meneliti perubahanperubahan mana yang perlu diadakan terhadap hukum yang ada agar memenuhi kebutuhan-kebutuhan baru di dalam kehidupan masyarakat. Berdasarkan atas posisi ilmu politik hukum dalam dunia 
ilmu pengetahuan seperti yang telah diuraikan maka objek ilmu politik hukum adalah "hukum".

Pelanggar ketentuan perundang-undangan tentunya tidak dianggap adil atau tidak memenuhi unsur keadilan, karena telah melakukan kecurangan, sehingga merugikan banyak pihak. Definisi demikian sampai pada taraf "keadilan" dalam pengertian hukum, sebagaimana dikemukakan Hans Kelsen. Keadilan baru dapat dinilai dari aspek kecocokan tindakan dengan hukum positif, terutama kecocokan dengan undang-undang yang berlaku. Pemilu dianggap adil jika pelaksanaannya sesuai dengan aturan yang ada (Fahmi, 2016 : 169). Keberadaan Mahar Politik dalam pemilukada akan menciderai pesta demokrasi yang sejatinya ditujukan untuk menumbuhkan nilai-nilai kejujuran, ketertiban, dan keadilan. Sebagaimana yang dinyatakan Wahyu Nugroho dalam jurnal Konstitusi (Nugroho, 2016: 483).

Pemilu dan pemilukada belum dimaknai secara lebih komprehensif sebagai cara yang berbudaya untuk menumbuhkan nilai-nilai kejujuran, ketertiban, dan keadilan, tetapi lebih mengedepankan keinginan untuk menang dengan segala cara, sekalipun melanggar norma hukum yang telah ditetapkan. Padahal, jika pemilu dan pemilukada sebagai proses pembudayaan, maka ia tidak menghendaki kekerasan, intimidasi, dan ketidakjujuran.

Salah satu pelangggaran yang terjadi dalam pemilu dan pilkada adalah lahirnya Mahar politik. Mahar politik seakan menjadi hal yang lumrah, karena dianggap sebagai ongkos perahu yang dalihnya nanti dijadikan sebagai dana pembiayaan untuk menjalankan roda kendaraan partai. Layar perahu kapal parpol dipastikan tidak akan terkembang, dan kapal parpol tidak akan berlayar untuk membawa diri sang calon kepala daerah bila mahar politik tidak dibayarkan.

Menurut M. Imam Nasef, Pengamat Hukum Tata Negara SIGMA, pengertian Mahar Politik Hukum terbagi dua, yaitu : Pertama, suatu imbalan khususnya dalam bentuk uang yang diberikan seorang calon kepada partai politik tertentu, dengan maksud agar parpol tersebut mencalonkan yang bersangkutan dalam Pilkada."Praktik semacam ini sering diistilahkan dengan 'jual-beli perahu', Kedua yakni mengacu pada sejumlah uang yang dipersiapkan untuk membantu biaya operasional keikutsertaan calon tertentu dalam suatu kontestasi Pilkada. 
Sedangkan menurut Suhud Alynudin, Mahar Politik merupakan sebuah konsekuensi dari sistem demokrasi yang ada di Indonesia, yaitu setiap warga negara dapat memilih langsung pemimpinnya. Akibat dari sistem itu, muncul biaya untuk membayar ongkos kampanye dan saksi pada pemungutan suara. Namun banyak kalangan tampak lebih mempresepsikan soal mahar dengan praktik "jual beli" dukungan (juga dalam pileg dan pilpres) dengan parpol".

Istilah Mahar dalam percaturan politik dipandang negatif, praktik mahar politik mencerminkan terjadinya pergeseran arti istilah atau konsep mahar (bahasa Arab mahr, bahasa Inggris dowry) dalam wacana publik Indonesia.

Istilah mahar politik dalam praktik politik Indonesia lebih satu dasawarsa terakhir, dipahami publik sebagai transaksi di bawah tangan atau illicit deal yang melibatkan pemberian dana dalam jumlah besar dari calon untuk jabatan yang diperebutkan (elected office) dalam pemilu/ pilkada dengan parpol yangmenjadi kendaraan politiknya.

Pada dasarnya, Undang-Undang Republik Indonesia Nomor 8 Tahun 2015 tentang Pemilihan Gubernur, Bupati dan Walikota telah tegas melarang adanya mahar politik. Undang-undang ini pun memberikan sanksi tegas bagi pelaku pemberi atau penerima uang mahar. Dalam Pasal 47 Undang-Undang Republik Indonesia Nomor 8 Tahun 2015 tentang Pemilihan Gubernur, Bupati dan Walikota, disebutkan adanya tiga bentuk sanksi bagi pelanggarnya dengan langkah :

Pertama; jika terbukti dengan putusan pengadilan yang berkekuatan hukum tetap, maka parpol yang bersangkutan dilarang mengajukan calon pada periode berikutnya di daerah yang sama. Kedua; terhadap pelaku pembayaran mahar politik tersebut, Komisi Pemilihan Umum (selanjutnya disingkat KPU) dapat membatalkan penetapan dirinya sebagai calon kepala daerah. Ketiga; parpol atau gabungan parpol yang terbukti menerima imbalan atau mahar akan didenda 10 kali lipat dari nilai yang diterima.

Pemilu dan pemilukada adalah cara menjinakkan kekerasan sekalipun untuk menang sebagai pemimpin. Hal ini menggantikan cara-cara pertumpahan darah seperti yang dilakukan raja-raja terdahulu dalam perebutan kekuasaan." 
Faktanya ternyata berkata lain, perilaku mahar politik masih menyeruak di mana-mana.

Dengan berlandaskan pada tradisi yang berpondasi pada akar transaksional tersebut hampir dipastikan calon kepala daerah ketika terpilih nanti tidak akan mementingkan masyarakat yang sudah memilihnya, sebaliknya, mereka akan mengupayakan berbagai cara untuk mengembalikan uang yang sudah dikeluarkannya lewat berbagai cara, termasuk dengan cara korupsi. Seolah ancaman inilah yang saat ini mendominasi. Saat uang menjadi penentu utama dalam prosesi pergantian pemimpin negeri.

Persoalan mahar politik merupakan salah satu yang membuat proses pencalonan membutuhkan waktu yang cukup lama, banyak partai yang mengambil injury time untuk mendaftar ke KPU yang sebenarnya menyiratkan adanya tarik menarik seberapa besar "mahar" yang dikeluarkan dan bahkan ada calon yang batal dicalonkan di detik-detik terakhir. Hal ini menjadi momentum yang penting untuk melihat bahwa ada persoalan serius dalam mekanisme pemilu yang membuat tarik menarik politik menguat yang ujungnya bisa menghadirkan praktik yang koruptif.

Esensi dan tujuan mahar politik sebetulnya sama dengan politik uang. Mahar politik ditujukan untuk mendapatkan dukungan dari partai politik untuk mencalonkan diri, sedangkan politik uang dimaksudkan untuk memperoleh dukungan dari pemilih. Selain berimplikasi terhadap tingginya biaya politik, mahar politik akan menghasilkan pemimpin yang tersandera oleh kepentingan segelintir elite. Karena itu, penting untuk mengawasi dan memastikan penegakan hukum terhadap pemberi dan penerima mahar politik.

Ada perbedaan mendasar mengenai pengaturan yang melarang mahar politik dalam Undang-Undang Pemilihan Kepala Daerah (Pilkada) dan Undang-Undang Pemilihan Umum (Pemilu). Perbedaan tersebut menyangkut hal-hal pokok yang seharusnya diperlakukan sama karena berada di dalam satu sistem pemilihan umum. Setidaknya ada dua aspek yang perlu dicermati. Pertama, dalam Undang-Undang Pilkada, sanksi yang diberikan tidak sebatas sanksi pidana (penjara/denda), tapi juga administratif. Pelanggar dilarang mengajukan calon kepala daerah/wakil kepala daerah untuk periode berikutnya. Sanksi lain adalah pembatalan atas penetapan pasangan calon, calon terpilih, dan kepala daerah yang telah dilantik. Adapun dalam Undang- 
Undang Pemilu, sanksi hanya sebatas pelarangan terhadap partai politik untuk mengajukan calon presiden/wakil presiden pada periode berikutnya. Aturan itu tidak menyebutkan soal pembatalan pasangan calon, calon terpilih, atau pemberhentian presiden dan wakil presiden yang telah dilantik.

Kedua, presiden dan parlemen lalai mengatur bagaimana memproses hukum pidana terhadap pemberi dan penerima mahar politik dalam UndangUndang Pemilu. Bab tentang ketentuan pidana di aturan itu tidak menyebutkan soal ancaman pidana bagi pemberi dan penerima mahar politik.

Ketika terjadi praktik mahar politik, ada dua langkah lain yang bisa dilakukan. Pertama, mahar politik itu akan dilihat sebagai sumbangan perorangan/badan usaha terhadap partai politik. Jika sumbangan tersebut melebihi batas yang diperbolehkan oleh undang-undang, ada ancaman pidana, baik terhadap penerima maupun pemberi, berupa hukuman penjara, denda, dan penyitaan sumbangan tersebut. Kedua, jika mahar politik tersebut kemudian ditujukan sebagai dana kampanye, perlu dilihat apakah jumlahnya melebihi ketentuan atau tidak. Selain itu, perlu ditelusuri apakah pengakuan tentang kesepakatan dana kampanye tersebut kemudian dilaporkan sebagai bagian dari laporan dana kampanye. Jika nanti muncul fakta bahwa mahar politik itu tidak pernah ada dalam laporan dana kampanye, hal tersebut bisa saja dikategorikan sebagai perbuatan memberikan keterangan tidak benar yang dapat berimplikasi secara hukum pidana.

Pemilu dan pemilukada sebagai salah satu bentuk nyata perwujudan demokrasi dalam pemerintahan daerah, seyogyanya juga semakin mencerminkan proses kematangan berdemokrasi. Walaupun demikian, implmentasi di lapangan masih menunjukkan adanya fenomena yang merusak citra pemilu dan pemilukada itu sendiri, seperti money politics, ketidaknetralan aparatur penyelenggara, kecurangan berupa pelanggaran kampanye dan penggelembungan suara, serta penyampaian pesan-pesan politik yang bernuansa sektarian berujung kepada retaknya bingkai harmonisasi kehidupan masyarakat. Pada segi lain, ketidaksiapandan ketidakdewasaan para kandidat dan pendukungnya untuk mensyukuri kemenangan dan menerima kekalahan yang sering diwujudkan dalam bentuk aksi-aksi yang menghalalkan segala cara, telah memicu konflik dan anarkisme massa di berbagai daerah. (Djoko Suyanto, $2012: 23)$. 
Politik hukum pemilu dan pemilukada mengalami perubahan terusmenerus seiring dengan perkembangan masyarakat, relevansi dalam praktik ketatanegaraan atau budaya berdemokrasi serta perubahan pemikiran hukum dan politik baik eksekutif, legislator maupun masyarakat pada umumnya. Melalui pengalaman pemilu presiden dan wakil presiden, pemilu untuk memilih anggota DPR, DPD dan DPRD, serta pemilihan kepala daerah, setidaktidaknya terdapat empat pihak yang mempengaruhi adanya perubahan politik hukum pemilu dan pemilukada yang pernah dialami di Indonesia, yakni: Pertama, DPR dalam hal mengajukan usulan dan membahas revisi undangundang pemilu/pilkada; kedua, Presiden dalam hal mengajukan usulan revisi Undang-Undang atau mengajukan Peraturan Pemerintah Pengganti UndangUndang (Perppu); ketiga, Mahkamah Konstitusi, dalam hal menguji UU/Perppu terhadap UUD 1945 dan menyelesaikan sengketa pemilu/pemilukada; dan keempat, Komisi Pemilihan Umum, melalui Peraturan KPU terkait pelaksanaan teknis dan aturan main dalam pemilu dan pilkada.

\section{KESIMPULAN}

Mahar Politik merujuk kepada transaksi di bawah tangan atau illicit deal yang melibatkan pemberian dana dalam jumlah besar dari calon untuk jabatan yang diperebutkan (elected office) dalam pemilu/pilkada dengan parpol yangmenjadi kendaraan politiknya, dan juga antar partai untuk membentuk koalisi lazim terjadi dan mencederai nilai-nilai demokrasi. Namun, hal itu sulit dibuktikan.

Mahar politik merupakan pelanggaran dalam Undang-Undang Pilkada, seharusnya proses pencalonan itu terjadi melalui kesepakatan antara partai politik dan kandidat yang akan diusung, Kesepakatan itu bisa berupa kesamaan visi antara pengurus parpol dan kandidat. Ketentuan dalam Undang-Undang Republik Indonesia Nomor 8 Tahun 2015 yang diubah dengan Undang-Undang Republik Indonesia Nomor 10 Tahun 2016 tentang Pilkada.

Politik hukum pemilu dan pemilukada mengalami perubahan terus-menerus seiring dengan perkembangan masyarakat, relevansi dalam praktik ketatanegaraan atau budaya berdemokrasi serta perubahan pemikiran hukum dan politik baik eksekutif, legislator maupun masyarakat pada umumnya. Melalui pengalaman pemilu presiden dan wakil presiden, pemilu untuk memilih anggota DPR, DPD dan DPRD, serta pemilihan kepala daerah, setidak-tidaknya terdapat empat pihak yang 
mempengaruhi adanya perubahan politik hukum pemilu dan pemilukada yang pernah dialami di Indonesia, yakni pertama, DPR dalam hal mengajukan usulan dan membahas revisi undang-undang pemilu/pilkada; kedua, Presiden dalam hal mengajukan usulan revisi Undang-Undang atau mengajukan Peraturan Pemerintah Pengganti Undang-Undang (Perppu); ketiga, Mahkamah Konstitusi, dalam hal menguji UU/Perppu terhadap UUD 1945 dan menyelesaikan sengketa pemilu/pemilukada; dan keempat, Komisi Pemilihan Umum, melalui Peraturan KPU terkait pelaksanaan teknis dan aturan main dalam pemilu dan pilkada. 


\section{DAFTAR PUSTAKA}

Asshiddiqie, Jimly, Konstitusi Dan Konstitusionalisme Indonesia, Sinar Grafika. Jakarta, 2010.

Efriza, Political Explore: Sebuah Kajian Ilmu Politik, Alfabeta, Bandung, 2012.

Fadjar, A. Mukthie, Tipe Negara Hukum, Bayumedia Publishing, Malang, 2005.

Mahfud MD, Hukum dan Pilar-Pilar Demokrasi, Gama Media, Yogyakarta, 1999

Politik Hukum di Indonesia, PT Raja Grafindo Persada, Jakarta, Cet. Ke5, 2012.

Mertokusumo, Sudikno, Mengenal Hukum: Suatu Pengantar, Liberty, Yogyakarta 1999.

Mind Community (GMC), Green,Teori dan Politik Hukum Tata Negara,Total Media, Yogyakarta, 2009.

Muliadi, Ahmad, Politik Hukum, Akademia Permata, Padang, 2013.

Ramses M., Andy. Dkk, Editor, Politik dan Pemerintahan Indonesia, Masyarakat Ilmu Pemerintahan Indonesia, Jakarta, 2009.

Undang-Undang Nomor 7 Tahun 2017 tentang Pemilihan Umum,

Undang-Undang Nomor 8 Tahun 2015 tentang Perubahan Pertama Atas UndangUndang Nomor 1 Tahun 2015 tentang Penetapan Peraturan Pemerintah Pengganti Undang-Undang Nomor 1 Tahun 2015 tentang Pemilihan Gubernut, Bupati, dan Walikota Menjadi Undang-Undang.

Undang-Undang Nomor 10 Tahun 2016 tentang Perubahan Kedua Atas UndangUndang Nomor 1 Tahun 2015 Tentang Penetapan Peraturan Pemerintah Pengganti Undang-Undang Nomor 1 Tahun 2014 tentang Pemilihan Gubernur, Bupati, dan Walikota Menjadi Undang-Undang. 